\title{
Management of pathogens in seed orchards and nurseries
}

\author{
by Jack R. Sutherland ${ }^{1}$
}

\begin{abstract}
The biology, damage and impact, and recent innovations in management of the major diseases affecting seed orchard trees and cones and forest nursery seedlings across Canada are discussed. Specific diseases covered are Armillaria root rot ( $A$. ostoyae) and inland spruce cone rust (Chrysomyxa pirolata) in seed orchards, and damping-off and root rots, especially Cylindrocladium floridanum, and gray (Botrytis cinerea) and storage moulds of forest nursery seedlings. Areas needing research are also mentioned.
\end{abstract}

Key words: Root rots, cone rust, damping-off, gray mould, storage moulds

\section{Résumé}

La biologie, les dégats et leurs impacts, ainsi que les récents progrès en gestion des principales maladies affectant les arbres de verger à graines, les cônes et les semis des pépinières forestières du Canada sont présentés dans cet article. Les maladies spécifiquement abordées sont le pourridié-agaric ( $A$. ostoyae) et la rouille des cônes de l'épinette de l'intérieur (Chrysomyxa pirolata) dans les vergers à graines, la fonte des semis et les rouilles des racines, spécialement Cylindrocladium floridanum, et la moisissure grise (Botrytis cinerea) ainsi que les moisissures d'entreposage des semis forestiers. Les domaines nécessitant plus de recherche sont aussi mentionnés.

Mots clés: Rouilles des racines, rouille des cônes, fonte des semis, moisissure grise, moisissures d'entreposage

\section{Introduction}

Numerous technological changes have occurred in both the science and practice of forestry in the past few years. Nowhere have such changes been more evident than in reforestation forestry where the development and establishment of seed orchards and container nurseries have had major impacts on the way seeds and seedlings are produced. Often, such technological changes eliminate or reduce the importance of specific pests, but frequently they result in certain pests, or new pests, becoming important. A classic example is production of container-grown seedlings which has practically eliminated damping-off losses which are so prevalent in bareroot nurseries. Conversely, gray mould (Botrytis cinerea Pers.), which seldom affects bareroot stock, is a major impediment in container nurseries. Because much time and effort, i.e. dollars, have been invested in new seed orchards and nursery facilities, it is only natural that today's foresters have become more aware of and concerned about pest-caused losses to their high value commodities. Consequently, seed orchard and nursery managers have become increasingly sophisticated in developing and implementing management practices to protect their crops. While many factors have contributed to improved pest management practices in seed orchards and nurseries, two overriding factors have been: (i) the accessibility of seed orchard trees which allows easy management and (ii) greater environmental control in container nurseries, vis-a-vis bareroot nurseries, particularly when seedlings are greenhouse-grown. Such nurseries allow environmental factors such as relative humidity to be manipulated for disease management. Recently, because of environmental and human health concerns, pesticide usage in seed orchards and nurseries has been drastically reduced. Managers of such establishments have thus adopted integrated pest management procedures including surveys for early

\footnotetext{
${ }^{1}$ Principal Research Scientist, Pacific Forestry Centre, Forestry Canada, 506 W. Burnside Rd., Victoria, British Columbia V8Z 1M5.
}

detection of pests and damage prediction, manipulation of cultural practices and better timing of pesticide applications to coincide with pest presence and abundance rather than routine, calendar-based pesticide applications. Biological control which so far has received scant attention in seed orchard and nursery disease management is now being researched and hopefully will become increasingly common in the future.

The purpose here is to review briefly some of today's major diseases of Canadian seed orchards and nurseries and describe how these diseases are managed. Readers wanting detailed information such as cycles of these and other diseases in Canadian seed orchards and nurseries should consult several recent publications (Bloomberg 1981; Griefenhagen et al. 1990; Sutherland 1984; Sutherland 1985; Sutherland et al. 1987). While I point out successes, I have also mentioned topics where more research is needed.

\section{Diseases in Seed Orchards}

Experience so far indicates that seed orchard trees and cones are mostly seriously affected by the same major diseases as in the forest. This contrasts with the nursery situation where most pathogens such as species of Fusarium and Botrytis seldom damage forest trees.

Disregarding classical seedling diseases that can affect seed orchard stock while it is in the propagation nursery, the disease most likely to first appear in conifer seed orchards is root rot. The main, and perhaps only root rot observed to date in conifer seed orchards has been Armillaria root rot (A. ostoyae (Romagn.) Herink). Experience in British Columbia and Ontario shows that trees begin to die within a year or so of being put into the orchard and losses continue over the next 10 or so years. Initial symptoms include basal resinosis, reduced terminal growth, needle chlorosis and desiccation, and then defoliation. Symptoms are most noticeable in late spring to early summer. Cutting away the bark at ground line reveals the characteristic whitish mycelial 
fans of the pathogen (Morrison 1981). Losses from Armillaria and other similar root rots can be avoided as inoculum originates from infested roots of diseased trees present on the forest site before it is cleared for orchard establishment. Sites previously used for agriculture and which contain no woody plants are of no risk because Armillaria inoculum dies out within a few years of being deprived of a woody food base. Establishing orchards on former farm land avoids the problem. However, since orchards are often established on former forest sites, these should be surveyed for root rots before removing the forest trees. During site clearing, all infested stumps and as much as possible of diseased root systems must be removed from the soil. Afterward, the site should be root raked to remove all small root pieces, down to pencil-size diameter. Better yet, the site should be cleared and raked 2 or 3 years before planting orchard trees to allow decay of small-diameter diseased root pieces which often serve as inoculum. Trees that die after orchard establishment should be flagged and, when there are enough dead trees to justify bringing in a backhoe, the diseased root systems and all inoculum from the original forest trees, including smalldiameter roots, should be removed from the soil and discarded off site. Replacement trees can be planted afterward, but delaying replanting for up to a year decreases the likelihood of the disease reappearing. Fungicides are ineffective against Armillaria and similar root rots, but soil fumigation may be worthwhile (e.g. Filip and Roth 1977).

Other root rot pathogens whose biology is similar to Armillaria, e.g. Inonotus tomentosus (Fr.) Teng, could cause root rots of seed orchard trees. Surveys and inoculum removal should be used when forest sites in which they occur are converted to seed orchards. Phytophthora spp. which are waterborne root rot pathogens, could be introduced into seed orchards via irrigation water, especially water previously used for agricultural purposes or runoff from farm fields. Suspected water supplies should be assayed for such pathogens.

Inland spruce cone rust (Chrysomyxa pirolata Wint.) causes the most damaging disease in spruce seed orchards in Canada. Cones of all spruces (Picea spp.) are affected. Depending upon locality, first symptoms of the disease appear about mid-summer when the surface of affected cones becomes covered with a sticky yellow-orange fluid. Breaking open a cone reveals masses of yellow-orange spermagonia on the cone scales. Lowermost scales frequently show symptoms first. By mid-late summer, scales of diseased cones become greenish-brown, then they turn brown and open prematurely, shedding copious amounts of yellow-orange aeciospores. These wind-borne spores infect alternate host plants (species of Pyrola and Monesis) which in the following and subsequent springs, about cone pollination time, produce wind-borne basidiospores on the underside of their leaves. Basidiospores infect spruce cones when they are upright and open for pollination. Other spores (urediniospores) are also produced, usually late in spring, on the undersurface of alternate host leaves. These wind-borne spores spread and intensify the pathogen on other alternate host plants. Within their distribution range, the alternate hosts, e.g. Pyrola spp., are often abundant in forest stands surrounding seed orchards (orchard conditions normally preclude their survival) and produce abundant wind-borne basidiospores that infect cones.

Plants of the various alternate hosts are often so abundant around seed orchards as to preclude use of herbicides. Using ground fire to eliminate alternate host plants around the orchard may have some merit, as could thinning nearby forest stands to increase light penetration, which is also detrimental to the alternate host plants. These measures may, however, be only cosmetic as the wind-borne basidiospores can be carried into orchards from alternate host plants several kilometres away. When feasible, the best solution is to avoid cone rust by locating seed orchards in areas without alternate host plants. For example, in a white spruce (Picea glauca (Moench) Voss) seed orchard at Salmon Arm, British Columbia, where Pyrola asarifolia Michx. and other alternate hosts are abundant in nearby forests, up to $60 \%$ of the cones can be affected by cone rust. In comparison, no cone losses occur at Vernon, $50 \mathrm{~km}$ south, in the dry Okanagan Valley where no alternate hosts occur. Although the problem may not be so easy to overcome elsewhere in Canada, proximity and abundance of cone rust alternate hosts should be a major criterion in selecting spruce orchard sites. Selecting a high hazard site almost certainly means that orchardists will have to protect cones at pollination time with fungicides such as ferbam (Summers et al. 1986).

Stem and gall rusts, e.g. western gall rust (Endocronartium harknessii (J.P. Moore) Y. Hiratsuka), which affect several hard or three-needle pines throughout Canada are potentially important in pine seed orchards. By affecting cone bearing branches they reduce the cone bearing potential of trees and, when present in the bole of a tree, they can result in bole breakage by wind or snow. The first remedy against stem and gall rusts is to prevent infection of planting stock in the nursery by protecting it with fungicides or for certain rusts by removing diseased trees (e.g. of western gall rust) and alternate host plants both within and adjacent to the orchard. Eliminating or reducing incidence of nearby rustaffected host trees or alternate host plants is very effective as rust intensity on seed orchard trees is often directly proportional to the distance from inoculum. Sutherland and Hunt (1990) and Ziller (1974) provide management guidelines for potential rust pathogens in the west.

In British Columbia, where we have some of Canada's oldest seed orchards, foliage diseases have generally caused only minor damage. Defoliation in a Douglas-fir orchard on Vancouver Island was related to cold water misting practices used to delay flowering. Needle damage and defoliation, caused by Hormonema merioides Funk, Woods and Hopkinson (Funk et al. 1985), were most severe nearest the misting stand pipes. The large size of the trees and abundance of senescent needles within their crowns may have contributed to the problem. Fungicide applications were of little benefit, but the problem disappeared after the trees were topped to facilitate cone picking.

\section{Diseases in Nurseries}

Just a few years ago, a discussion of nursery diseases would have been restricted to bareroot nurseries. Today we must also include diseases of container-grown seedlings as more and more of Canada's forest nursery seedlings are being produced in containers. For example, almost all of British Columbia's annual seedling production is now from container nurseries. Most of the major diseases of bareroot seedlings, i.e. damping-off and root rots, are caused by soil-borne pathogens such as species of Cylindrocladium and Fusarium. such pathogens are seldom serious in container nurseries 
because the growing media (peat plus various additives) are normally pathogen-free; however, previously-used growing containers frequently harbor pathogens. Instead of being plagued by "soil-borne" pathogens, container-grown seedlings are more prone to seed-borne and foliage diseases. The advent of container nurseries has not put pathogens out of business!

Over the years, damping-off and root rots have consistently been of concern to bareroot nursery managers. Preemergence damping-off, as the name implies, kills seeds or germinants before they emerge from the soil while postemergence damping-off rots the seedling stem near groundline. Losses can reach $80 \%$ of the seeds sown. Postemergence damping-off ceases to be a problem once seedling stems become woody. Thus, cultural practices and environmental factors that inhibit woody stem development favor this disease. One such cultural practice is application of nitrogenous fertilizers to germinants and young seedlings reputedly nitrogen fertilization makes seedlings succulent. Early Canadian studies on control of damping-off focused on applying fungicides to seeds (Carlson 1972; Vaartaja 1956), but "the magic bullet" is elusive because phytotoxicity of most fungicides was found to kill as many or more seeds and germinants as they protect from damping-off, especially when disease pressure is low. Thus, screening trials of 326 fungicides produced only six that resulted in a net gain in seedling numbers - and four of these contained either thiram or the current day scourge, captan. Another problem with seed-applied fungicides is that their continuous use results in build up of fungicide-resistant pathogens and this leads to inadequate damping-off control. When effective fungicides are available, they should be used in rotation. Since both damping-off and root rots are usually caused by the same pathogens, other practices useful against damping-off are given in the following section on root rots.

In recent years, root rots such as Cylindrocladium root rot (C. floridanum Sob. \& Seymour) have caused particularly severe losses in Ontario and Quebec nurseries (Greifenhagen et al. 1990, Juzwik et al. 1988). Cylindrocladium is especially hard to control as it forms microsclerotia (hardened masses of vegetable growth) resistant to cold and heat, drying and pesticides. Besides Cylindrocladium, several other root rot pathogens such as in the genera Fusarium, Pythium, Phytophthora and Rhizoctonia occur in Canadian bareroot nurseries. Seedling root rots decay primary and secondary roots, resulting in seedlings being culled either because of disease damage or insufficient height and root collar diameter. Root rots can be more serious on certain hosts or age classes; Cylindrocladium, for example, is most damaging on black spruce (Picea mariana (Mill.) B.S.P.) transplants in Ontario (Juzwik et al. 1987). Root rot losses depend upon presence of both a susceptible host and a pathogen in a suitable environment, as do losses from all diseases. Although nursery managers are loath to admit it, they often create a suitable environment by using inappropriate cultural practices.

Since several pathogens cause both damping-off and root rots, many of the same practices are useful against the two diseases. Adjusting soil pH to 4.5 to 5.5 (a range generally unfavorable to these pathogens) is a simple, worthwhile practice as is improving soil drainage. Cultural practices useful against damping-off include: (i) spring sowing of stratified seeds which germinate quickly, (ii) delaying sowing until soils are warm enough to favor germination, (iii) covering sown seeds with a non-compacting material such as sand to facilitate germinant emergence, and (iv) using fields with persistent, serious damping-off for transplants. Seedlots with persistent damping-off histories should be checked for seedborne pathogens, such as the seed or cold fungus (Sutherland et al. 1989) which cause pre-emergence damping-off, especially of spruce, and Fusarium (James 1985) which can cause both pre- and post-emergence losses on many species. Soil fumigation with chemicals including methyl bromide (e.g. Sutherland 1967) and mylone (Testa and Juzwik 1989) may be justified for damping-off and root rot control, particularly in nurseries with other problems (weeds and insects). However, use of such soil fumigants could be banned because of possible health, safety and environmental concerns. In British Columbia, we do not use green manure (cover crops) because they favor build up and survival of damping-off and root rot pathogens; peat is used to maintain soil organic matter. We also bare-fallow and summer cultivate fields each year between seedling crops. Of course, the best prevention for damping-off and root rot (and other soil-borne diseases) is to initially select a nursery site with a well drained, sandy to sandy loam soil. Besides their many other advantages, e.g. few problems at seedling lifting, such soils are much less favorable to, and easier to rid of pathogens.

Gray mould, caused by the fungus Botrytis cinerea, is the most damaging disease of container-grown seedlings across Canada. All broadleaf and conifer crops are affected, but pines, spruces, Abies spp., hemlocks and Douglas-fir are very susceptible. Symptoms appear in late summer and early fall on 1-0 seedlings as a grayish-brown mould on the lowermost needles. Moulded needles become watersoaked and die. Under cool $\left(15-20^{\circ} \mathrm{C}\right)$, wet $(\mathrm{RH}>98 \%)$ conditions the pathogen spreads, via vegetative growth, upward on the seedling shoot and laterally to nearby seedlings. Roots remain unaffected. Under favorable conditions, up to $80 \%$ of a crop can be affected. Besides killing needles, the fungus sometimes enters woody stems and kills seedlings. Incipient mould can continue to develop on cold-stored stock and during transit to, and storage at, the planting site. Air-borne, spores have been trapped throughout the growing season. In fact, greenhouse fans act like giant spore traps, sucking the airborne spores into houses. Inoculum originates from dead organic matter in the forests and fields around the nursery or dead weeds and cull piles in the nursery. Since conditions favoring infection are most prevalent in summer, infection in the summer likely takes place on senescent needles in the lowermost part of the seedling shoot. Disease development and spread via vegetative growth occurs after seedling canopy closure in mid-late summer and thereafter. Beside cool temperatures and high moisture, dense foliage and crowded seedlings also enhance gray mould. In Quebec, gray mould can proliferate on stock overwintered outdoors, becoming evident with spring snow melt.

Presently, a combination of cultural practices and fungicides are used against gray mould. Fungicides alone will not provide adequate control. Humidity can be reduced by improving ventilation, or reducing or stopping watering. Ventilation can be improved by re-arranging growing containers with spaces between containers. Increasing greenhouse temperatures, then exhausting laden air also helps. 
Another recent innovation is the Ventblock ${ }^{\circledR}$, a seedling growing container which was marketed following our research (Peterson and Sutherland 1990). Ventblocks allow nurseries to use underbench ventilation to force air through the seedling canopy, thereby decreasing the duration of needle wetness periods favoring gray mould. Results are best when a combination of these practices are used.

Poor greenhouse lighting caused by the inability of sunlight to penetrate old and dirty fiberglass and other greenhouse covering is a major factor in gray mould outbreaks (Peterson et al. 1988). Poor lighting results in taller, more succulent seedlings and canopy closure earlier in the growing season, conditions all favorable to the disease. Nursery sanitation to remove gray mould and other diseased or dead seedlings, cull piles and weeds deprives the pathogen of material upon which to sporulate. In conjunction with cultural practices, protectant and systemic fungicides are also used to battle gray mould. In British Columbia, when fungicides are needed they are applied just before canopy closure and again before seedling lifting. Quebec nurseries apply fungicides late in the autumn to prevent gray mould damage on seedlings overwintered outdoors under snow. Timing and thoroughness of fungicide application are important in obtaining good control. Gray mould strains often develop that are resistant to certain fungicides, thus laboratory tests should be made regularly for such strains. Biological control studies for gray mould control are now underway in Ontario and British Columbia. More research is needed in this area as well as on the effect of cultural practices such as fertilizer regimes on seedling susceptibility.

Storage moulds are particularly important as they affect the nursery's final product. For that reason they have a significant financial impact. In British Columbia, and likely elsewhere, moulding of stored container seedlings is mainly caused by gray mould which continues to develop after becoming established in the nursery. In contrast, a wide variety of soil-borne fungi including species of Penicillium, Aspergillus, and Cylindrocarpon mould stored bareroot stock. Research is needed on this disease as almost nothing is known about the pathogenicity of these fungi, how their abundance relates to damage, or which conditions favor the disease. Although these fungi could get onto seedlings in several ways, much foliage contamination occurs during seedling lifting and sorting. All species of conifers are affected, but perhaps pines are less susceptible. Transplants are extremely susceptible. Initial symptoms often appear as a proliferation of mould growth on the lower shoot, especially around twine used to secure seedling bundles. As the disease progresses, mould-covered stems and needles become watery, rotted, smell mouldy and often give off clouds of spores. The cambium of killed tissues is usually butterscotch colored.

Storage mould of container-grown seedlings is best controlled by preventing establishment of gray mould on seedlings before storage. Pre-storage application of fungicides to both container-grown and bareroot seedlings may be more of a therapeutic treatment for the nursery manager than a control for the disease. Removing diseased stock from storage and dipping it in fungicide is only recommended for those who must do something! More practical remedies include storing seedlings for the shortest period possible and frequent examination of stored seedlings for moulding. If possible, stock with incipient moulding should be field-planted quickly. Seedlots with significant amounts of dead needles, such as those killed by frost and fertilizer burns and the like, are very susceptible to storage moulds. Where applicable, storing and seedlings at -1 to $-2{ }^{\circ} \mathrm{C}$ prevents moulding, but moulding can occur during thawing.

\section{References}

Bloomberg, W.J. 1981. Diseases caused by Fusarium in forest nurseries. In Fusarium: Diseases, Biology, and Taxonomy (P.E. Nelson, T.A. Toussoun, and R.J. Cook eds). The Pennsylvania State Univ. Press, University Park, pp. 178-187.

Carlson, L.W. 1972. Forest tree nursery disease control. In Proc. Joint Meeting, Western Forest Nursery Council and Intermountain Forest Nurserymen's Assoc., Olympia, WA., pp. 111-114.

Filip, G.M. and L.F. Roth. 1977. Stump injections with soil fumigants to eradicate Armillariella mellea from young-growth ponderosa pine killed by root rot. Can. J. For. Res. 7: 226-231.

Funk, A., T.A.D. Woods and S.J. Hopkinson. 1985. Hormonema merioides n. sp., on Douglas-fir needles. Can. J. Bot. 63: 1579-1581.

Griefenhagen, S., C. Davis, J.R. Sutherland and J. Juzwik. 1990. Diseases and insects in Canadian forest nurseries. In Proc. IUFRO Working Party S2.07-09 (Diseases and Insects in Forest Nurseries). Victoria, B.C., August 22-30, 1990. (in press).

James, R.L. 1985. Diseases of conifer seedlings caused by seedborne Fusarium species. In Proc. - Conifer Tree Seed in the Inland Mountain West Symposium, Missoula, MT, pp. 267-269.

Juzwik, J., B.H. McGauley and K.H. Reese. 1987. Status and control of Cylindrocladium root rot in Ontario provincial forest nurseries. In Proc. of Nyrserymen's Meeting, June 18-20, 1987, Dryden, Ont., pp. 4-10.

Juzwik, J., C. Honhart and N. Chong. 1988. Cylindrocladium root rot in Ontario bare-root nurseries: estimate of spruce seedling losses. Can. J. For. Res. 18: 1493-1496.

Morrison, D.J. 1981. Armillaria root disease a guide to disease diagnosis, development and management in British Columbia. Can. For. Serv., Pac. For. Res. Cent., Victoria, B.C. Inf. Rep. BC-X-203. 15 p.

Peterson, M.J., J.R. Sutherland and S.E. Tuller. 1988. Greenhouse environment and epidemiology of grey mould of container-grown Douglas-fir seedlings. Can. J. For. Res. 18: 974-980.

Peterson, M.J., J.R. Sutherland. 1990. Controlling gray mould on container-grown Douglas-fir by modified styroblocks and under-bench, forced-air ventilation. West. J. Appl. For. 5: 75-79.

Summers, D., J.R. Sutherland and T.A.D. Woods. 1986. Inland spruce cone rust (Chryomyxa pirolata) control: relation of ferbam application to basidiospore production, rainfall, and cone phenology. Can. J. For. Res. 16: 360-362.

Sutherland, J.R. 1967. Field tests for the control of red pine seedling diseases. Phytoprotection 48: 58-67.

Sutherland, J.R. 1984. Pest management in northwest bareroot nurseries. Production of bareroot seedlings (M.L. Duryea and T.D. Landis ed). Martinus Nijhoff/Dr. W. Junk Publishers, The Hague, pp. 203-210.

Sutherland, J.R. 1985. Influence of diseases on seed production. In Proceedings - Conifer Tree Seed in the Inland Mountain West Symposium, Missoula, MT, pp. 260-266.

Sutherland, J.R., T. Miller and R. Salinas Quinard. 1987. Cone and seed diseases of North American conifers. North Am. 
Forest. Comm. Publ. No. 1, Ottawa, Washington, D.C. and Mexico City. 77 pp.

Sutherland, J.R., G.M. Shrimpton and R.N. Sturrock. 1989. Diseases and insects in British Columbia forest seedling nurseries. FRDA Rep. No. 065, Victoria, B.C. 85 p.

Sutherland, J.R. and R.S. Hunt. 1990. Diseases in reforestation. In Regenerating British Columbia's Forests (D.P. Lavender, R. Parish, C.M. Johnson, C. Montgomery, A. Vyse, R.A. Willis, and D. Winston eds). University of British Columbia Press, Vancouver, pp. 266-278.
Testa, F. and J. Juzwik. 1989. Effect of repeated cultivation during summer fallow on Cylindrocladium floridanum in two Ontario forest nurseries. Can. Plant Dis. Survey 69: 129-133.

Vaartaja, O. 1956. Screening fungicides for controlling dampingoff of tree seedlings. Phytopathology 46: 387-390.

Ziller, W. 1974. The tree rusts of western Canada. Dep. Environ., Can. Forest. Serv., Publ. No. 1329, Ottawa, Ontario. 272 p.

\section{NRC RESEARCH JOURNALS 1992 SUBSCRIPTION RATES}

\begin{tabular}{|c|c|c|c|c|c|c|}
\hline \multirow{4}{*}{ Monthly } & \multirow{3}{*}{\multicolumn{2}{|c|}{ Institutional Personal }} & \multirow{3}{*}{\multicolumn{2}{|c|}{ Institutional Personal }} & \multirow{3}{*}{$\begin{array}{l}\text { Mandatory } \\
\text { Subscription } \\
\text { with } \\
\text { Membership }\end{array}$} & SOCIETY \\
\hline & & & & & & Nonmandatory \\
\hline & & & & & & Membership \\
\hline & & & & & & \\
\hline Biochemistry \& Cell Biology & $\$ 220$ & $\$ 82$ & $\$ 220$ & $\$ 84$ & $\$ 28$ & $\$ 32$ \\
\hline Can. J. Botany & 316 & 125 & 316 & 135 & 50 & 55 \\
\hline Can. J. Chemistry & 414 & 131 & 414 & 141 & 51 & 57 \\
\hline Can. J. Earth Sciences & 311 & 100 & 311 & 105 & 43 & 48 \\
\hline Can. J. Forest Research & 273 & 89 & 273 & 91 & 34 & 39 \\
\hline Can. J. Microbiology & 223 & 88 & 223 & 90 & 33 & 38 \\
\hline Can. J. Physics & 278 & 92 & 278 & 95 & 32 & 37 \\
\hline *Can. J. Physiol. Pharmacol. & 325 & 106 & 325 & 109 & 47 & 52 \\
\hline Can. J. Zoology & 338 & 140 & 338 & 140 & 51 & 58 \\
\hline Bimonthly & & & & & & \\
\hline Can. J. Civil Engineering & 218 & 71 & 218 & 73 & 26 & 30 \\
\hline Genome & 202 & 83 & 202 & 85 & 25 & 29 \\
\hline Can. Geotechnical J. & 174 & 66 & 174 & 72 & 24 & 29 \\
\hline
\end{tabular}

*Canadian Journal of Physiology and Pharmacology will publish a 13th issue in 1992 (Third International Symposium on Excitation Contraction Coupling).

Special rates apply for members of Canadian scientific and engineering societies if they subscribe through their respective societies.

Single copy price for 1992 issues Canada: Institutions, \$38; Individuals, \$19

Foreign: Institutions, \$US 38; Individuals, \$US 19 